University of Nebraska - Lincoln

DigitalCommons@University of Nebraska - Lincoln

1995

\title{
Environmental Modification of Hard Red Winter Wheat Flour Protein Composition
}

\author{
Robert A. Graybosch \\ University of Nebraska-Lincoln, bob.graybosch@ars.usda.gov \\ C. J. Peterson \\ University of Nebraska-Lincoln \\ P. Stephen Baenziger \\ University of Nebraska-Lincoln, pbaenziger1@unl.edu \\ D. R. Shelton \\ University of Nebraska-Lincoln
}

Follow this and additional works at: https://digitalcommons.unl.edu/usdaarsfacpub

Part of the Agricultural Science Commons

\author{
Graybosch, Robert A.; Peterson, C. J.; Baenziger, P. Stephen; and Shelton, D. R., "Environmental \\ Modification of Hard Red Winter Wheat Flour Protein Composition" (1995). Publications from USDA-ARS / \\ UNL Faculty. 917. \\ https://digitalcommons.unl.edu/usdaarsfacpub/917
}

This Article is brought to you for free and open access by the U.S. Department of Agriculture: Agricultural Research Service, Lincoln, Nebraska at DigitalCommons@University of Nebraska - Lincoln. It has been accepted for inclusion in Publications from USDA-ARS / UNL Faculty by an authorized administrator of DigitalCommons@University of Nebraska - Lincoln. 


\title{
Environmental Modification of Hard Red Winter Wheat Flour Protein Composition
}

\author{
R. A. Graybosch*, C. J. Peterson*, P. S. Baenziger† and D. R. Shelton† \\ *USDA-ARS, University of Nebraska, Department of Agronomy, Lincoln, Nebraska, 68583, and \\ †Department of Agronomy, University of Nebraska, Lincoln, Nebraska, 68583, U.S.A.
}

Received 8 July 1994

\begin{abstract}
The intrinsic processing quality of wheat (Triticum aestivum L.) cultivars is modified significantly by cultural conditions and climate. In an attempt to understand the biochemical basis of such variation, environmental modification of flour protein content and composition was measured. Thirty hard red winter wheat cultivars and experimental lines were grown at 17 Nebraska environments during 1990 and 1991. Environmental conditions, including grain filling duration, temperature and relative humidity during grain filling, were monitored. Grain yield and test weight also were determined as environmental indicators. Significant linear correlations between flour protein content, as measured by near-infrared spectroscopy, were observed only with the duration of grain filling. Protein quality, as measured by SDS sedimentation volumes and size-exclusion high-performance liquid chromatography, was highly influenced by the frequency of high temperatures during grain filling and by the relative humidity. Observed ranges in genotypic responses (variance) at locations also were altered by environmental factors. Optimal protein quality, as determined by SDS sedimentation volumes, was observed with exposure to less than $90 \mathrm{~h}$ of temperature greater than $32^{\circ} \mathrm{C}$ during grain filling. Protein quality declined with exposure to a greater number of hours of elevated temperature.

(c) 1995 Academic Press Limited
\end{abstract}

\section{INTRODUCTION}

Wheat (Triticum aestivum $\mathrm{L}$.) is a species adapted to diverse cultural environments and end-uses, and wheat intended for specific end-uses is exposed to variable environmental conditions, both within and across harvest years. Modern large-scale plant bakery operations demand uniformity of flour shipments. Grain purchasers and millers are faced with the daunting challenge of providing uniform flour from grain produced under a shifting mosaic of cultural environments. Millers and grain buyers also must provide wheat for diverse procedures used in commercial operations. Even users of identical market classes of wheat may have different specifications, depending upon the bake methods of their product lines.

ABBREviations usED: SDS, sodium dodecyl sulfate; SEHPLC, size exclusion high-performance liquid chromatography; SUP, saline unextractable protein; SEP, saline extractable protein.
Wheat quality is influenced by genotype (cultivars grown), environmental factors, and the interaction of genotype and environment ${ }^{1,2,3,4}$. In the Great Plains of North America, environmental variances associated with quality traits often exceed genotypic variances ${ }^{4,5}$. In the U.S.A., most wheat is bought and sold in the absence of any cultivar identification. Thus, knowledge of environmental factors may be the primary means by which grain buyers and millers can make informed decisions regarding optimal production regions for the acquisition of quality grain.

Fortunately, data on environmental conditions is readily available in many countries through the establishment of automated weather data networks ${ }^{6}$. The accessibility of weather data through 'on-line' computer networks suggests the possibility of implementing environmental models for the prediction of crop quality, as has been accomplished for crop yield ${ }^{7}$. The diverse quality requirements of the wheat industry complicate the process, however. An alternative approach could 
be to develop predictive models for flour biochemical attributes. Different users of wheat could then determine relationships between biochemical variation and their own quality specifications. Environmentally based predictive models for wheat biochemical characteristics might then predict flour quality indirectly.

Flour protein content and composition are primary determinants of flour quality ${ }^{8}$. Several studies have attempted to correlate flour protein content or composition with environmental factors. Johnson et al. ${ }^{9}$ found a slight positive correlation between increased temperatures during the early stages of grain filling and protein content; higher average temperatures late in grain filling showed no effect on protein content. Rao et al. ${ }^{10}$ found the protein content of soft white winter wheat to be associated positively with maximum temperatures during grain filling; however, the relationships were found to vary among sites. Additional climatic variables, especially night-time temperatures, were found to influence protein content. Blumenthal $e t$ al. ${ }^{11.12}$ described a loss of dough strength in Australian wheats proportional to the number of hours on high temperatures $\left(>35^{\circ} \mathrm{C}\right)$ during grain filling. Blumenthal et al. ${ }^{12}$ proposed that this effect was due to a differential synthesis of monomeric (gliadin) proteins, as opposed to glutenin, during periods of heat stress. Cultivars differed in their response to field heat stress, however.

The experiment reported herein was designed to identify possible relationships between flour biochemical attributes, namely protein content, protein quality and composition, and environmental factors, as encountered under typical Great Plains field conditions. The extent to which combinations of environmental variables could be used to predict biochemical responses was also investigated.

\section{EXPERIMENTAL}

Thirty hard red winter wheat genotypes (cultivars and experimental lines) were grown in randomised complete block designs with two replications at the following Nebraska locations in 1990 and 1991: Lincoln, Clay Center, North Platte, McCook, Grant, Alliance, Scottsbluff and Sidney. At Sidney, the study was seeded under both dryland and irrigated conditions, with the two plantings being treated as separate environments. The Alliance location was lost due to winterkill in 1991; hence, the final analysis included 17 environments. Each year $\mathrm{X}$ location combination was treated as a separate environment. The duration of grain filling was recorded at each site as the number of days from anthesis to harvest maturity. Both grain yield and test weight were determined.

Environmental data for each location were obtained from the Nebraska Automated Weather Data system ${ }^{6}$. Hourly readings of temperature, relative humidity and precipitation were available. For ease of analysis, data were condensed to the following variables: hours of temperature $>32^{\circ} \mathrm{C}$ during grain filling, hours of temperature $>35^{\circ} \mathrm{C}$ during grain filling, hours of temperature $<21^{\circ} \mathrm{C}$ during grain filling, hours of night-time temperature $<21{ }^{\circ} \mathrm{C}$ during grain filling, hours of relative humidity $<40 \%$ during grain filling, hours of stress (defined as the total number of hours of combined temperatures of $>29^{\circ} \mathrm{C}$ and relative humidity $<40 \%)$.

Grain $(50 \mathrm{~g})$ from each replication was tempered to a moisture basis of $15.2 \%(\mathrm{w} / \mathrm{w})$ and milled on a Brabender Quadraplex experimental mill (C.W. Brabender Instruments Inc., South Hackensack, NJ). Flour was separated from bran using a Strand (Minneapolis, MN) shaker at $225 \mathrm{rev} / \mathrm{min}$ for $90 \mathrm{~s}$ with a U.S. Standard Sieve no. 70.

Flour protein content ( $0 \%$ moisture basis) was measured by near-infrared spectroscopy (NIR). SDS sedimentation volume, a measure of protein quality, was measured from a $2 \mathrm{~g}$ flour sample at a moisture basis of $14.0 \%(\mathrm{w} / \mathrm{w})$ using approved method $56-61 \mathrm{~A}^{13}$. Flour protein composition was analysed using SE-HPLC ${ }^{14,15}$. Briefly, flour samples $(25 \mathrm{mg})$ were sonicated sequentially in (1) $0.04 \mathrm{M} \mathrm{NaCl}$ and (2) $2 \%(\mathrm{w} / \mathrm{v})$ SDS in $0.05 \mathrm{~m}$ $\mathrm{Na}$ phosphate buffer, $\mathrm{pH} 6 \cdot 9$, using a Tekmar (Cincinnati, $\mathrm{OH}$ ) Sonic disrupter at a power setting of 5 watts for $30 \mathrm{~s}$. The protein content of five fractions, glutenin, gliadin, low $M_{\mathrm{r}}(<25 \mathrm{k})$ saline unextractable protein (SUP), high $M_{\mathrm{r}}(25 \mathrm{k}-100 \mathrm{k})$ saline extractable protein (SEP), and low $M_{\mathrm{r}}(<25 \mathrm{k})$ SEP were measured after separation of protein extracts on a BioRad (Richmond, CA) HPLC fitted with a Waters Protein-Pak 300 sw silica column $(10 \mu \mathrm{m}$, pore size $30 \mathrm{~nm})$. Protein in the column effluent was determined by UV absorption at $210 \mathrm{~nm}$. Values were expressed as proportion (\%) of total extracted protein.

Statistical Analysis System ${ }^{16}$ programs and procedures were used for the analysis of data. Simple 
Table I Mean responses, standard deviations and ranges for environmental variables over locations

\begin{tabular}{|c|c|c|c|c|}
\hline Variable & Mean & $\begin{array}{l}\text { Standard } \\
\text { deviation }\end{array}$ & Minimum & Maximum \\
\hline Hours ${ }^{\mathrm{a}}$ of temperature $>32^{\circ} \mathrm{C}$ & $77 \cdot 9$ & $31 \cdot 9$ & $28 \cdot 0$ & $137 \cdot 0$ \\
\hline Hours ${ }^{\mathrm{a}}$ of temperature $>35^{\circ} \mathrm{C}$ & $36 \cdot 3$ & $36 \cdot 3$ & $6 \cdot 0$ & $71 \cdot 0$ \\
\hline Hours $^{\mathrm{a}}$ of relative humidity $<40 \%$ & $172 \cdot 8$ & $145 \cdot 7$ & $21 \cdot 0$ & $482 \cdot 0$ \\
\hline Hours stress ${ }^{b}$ & $83 \cdot 9$ & $52 \cdot 5$ & $16 \cdot 0$ & 193.0 \\
\hline Hours ${ }^{\mathrm{a}}$ of temperature $<21^{\circ} \mathrm{C}$ & $473 \cdot 3$ & $74 \cdot 9$ & $318 \cdot 0$ & $567 \cdot 0$ \\
\hline $\begin{array}{l}\text { Night-time hours }{ }^{a} \text { of temperature } \\
<21^{\circ} \mathrm{C}\end{array}$ & $434 \cdot 1$ & $62 \cdot 4$ & $290 \cdot 0$ & $512 \cdot 0$ \\
\hline Grain filling duration (days) & $40 \cdot 7$ & $3 \cdot 4$ & 32 & 45 \\
\hline Grain yield (kg/ha) & $3035 \cdot 7$ & $970-4$ & $1210 \cdot 50$ & $4909 \cdot 2$ \\
\hline Test weight $(\mathrm{kg} / \mathrm{hl})$ & $74 \cdot 8$ & $3 \cdot 1$ & $68 \cdot 9$ & $79 \cdot 7$ \\
\hline
\end{tabular}

correlations were calculated between flour protein variables and each environmental factor. Mean response of the 30 genotypes at each location was used as the dependent variable. Also, variances in genotypic responses at each location were correlated with environmental factors. To minimize the dependence of variances upon means, logarithmic (base 10) transformations were performed before the calculation of correlation coefficients ${ }^{16}$. To identify possible non-linear relationships between biochemical and environmental variables, goodness of fit of second order polynomial (quadratic) curves was tested ${ }^{16}$. Stepwise multiple regression was used to determine the proportion (\%) of total variation of each biochemical factor attributable to the combined effects of environmental factors. Inclusion of an independent variable within stepwise models required a probability level of $0 \cdot 15$.

\section{RESULTS}

Environments were characterised in terms of climatic factors and productivity (Table I). Broad ranges in all the measured variables were observed. Flour biochemical attributes for each environment are given in Table II. A relatively narrow range of response was observed for glutenin compared with all the other biochemical variables.

Simple correlations between environmental variables and flour biochemical attributes are given in Table III. The mean protein content was correlated significantly only with the duration of grain filling. Protein quality (SDS sedimentation vol- ume), in contrast, was highly negatively correlated with both hours of high temperature and hours of low relative humidity during grain filling. Glutenin and gliadin were affected negatively by increased temperatures during grain filling, while low $M_{\mathrm{r}}$ SUP and high $M_{\mathrm{r}}$ SEP were enhanced under higher temperatures. Grain yield and test weight were unrelated to most biochemical variables, with the exception of positive correlations between glutenin content and grain yield, positive correlations between test weight and gliadin, and negative correlations between test weight and high $M_{\mathrm{r}}$ SEP.

Significant correlations were observed between variances of flour protein content, low $M_{\mathrm{r}} \mathrm{SUP}$, low $M_{\mathrm{r}}$ SEP and SDS sedimentation volume and environmental parameters (Table IV). Increased frequency of high temperatures during grain fill resulted in decreased variances for protein content and SDS sedimentation volumes, and increased the variance associated with low $M_{\mathrm{r}}$ SUP. Increased frequency of cool night-time temperatures resulted in an increased variance for flour protein content and a decreased variance for low $M_{\mathrm{r}}$ SEP. Genotypic differences in both protein content and SDS sedimentation volumes, therefore, were more easily detected in the lower stress environments.

Simple correlations do not reveal non-linear relationships. Analysis of variance was used to test for goodness of fit of a non-linear distribution (second order polynomial); among all tested variables, only SDS sedimentation volume fit such a distribution. The relationship between SDS sedimentation volumes and both hours of temperature during grain filling $>32^{\circ} \mathrm{C}$ (Fig. l) and hours of temperature during grain filling $>35^{\circ} \mathrm{C}$ (not 
Table II Mean responses, standard deviations and ranges, of flour biochemical variables measured at 17 locations

\begin{tabular}{|c|c|c|c|c|}
\hline Variable & Mean & $\begin{array}{l}\text { Standard } \\
\text { deviation }\end{array}$ & Minimum & Maximum \\
\hline Flour protein content (\%) & $12 \cdot 86$ & $1 \cdot 79$ & $9 \cdot 69$ & $17 \cdot 73$ \\
\hline Glutenin $(\%)$ & $41 \cdot 25$ & 0.74 & $40 \cdot 20$ & $42 \cdot 97$ \\
\hline Gliadin $(\%)$ & $35 \cdot 23$ & 3.04 & $27 \cdot 63$ & $41 \cdot 77$ \\
\hline Low $M_{\mathrm{r}}$ SUP & $7 \cdot 39$ & $1 \cdot 37$ & $6 \cdot 14$ & $10 \cdot 59$ \\
\hline High $M_{r}$ SEP & $11 \cdot 34$ & 1.55 & $8 \cdot 33$ & $13 \cdot 55$ \\
\hline Low $M_{\mathrm{r}}$ SEP & $4 \cdot 78$ & 0.87 & $3 \cdot 74$ & $7 \cdot 35$ \\
\hline SDS sedimentation volume (ml) & $32 \cdot 21$ & $4 \cdot 50$ & $21 \cdot 42$ & $38 \cdot 58$ \\
\hline
\end{tabular}

Table III Correlations of environmental parameters with location means, flour biochemical traits

\begin{tabular}{|c|c|c|c|c|c|c|c|}
\hline & $\begin{array}{l}\text { Flour } \\
\text { protein } \\
\text { content }\end{array}$ & Glutenin & Gliadin & $\begin{array}{l}\text { Low } M_{\mathrm{r}} \\
\text { SUP }\end{array}$ & $\begin{array}{l}\text { High } M_{\mathrm{r}} \\
\text { SEP }\end{array}$ & $\begin{array}{l}\text { Low } M_{\mathrm{r}} \\
\text { SEP }\end{array}$ & $\begin{array}{l}\text { SDS sedimentation } \\
\text { volume }(\mathrm{ml})\end{array}$ \\
\hline Hours ${ }^{\mathrm{a}}$ of temperature $>32^{\circ} \mathrm{C}$ & -0.01 & $-0.55^{*}$ & $-0 \cdot 46$ & $0 \cdot 61^{* *}$ & $0 \cdot 49 *$ & $0 \cdot 23$ & $-0 \cdot 63^{* *}$ \\
\hline Hours ${ }^{a}$ of temperature $>35^{\circ} \mathrm{C}$ & -0.03 & $-0 \cdot 55^{*}$ & $-0 \cdot 44$ & $0 \cdot 56^{*}$ & $0 \cdot 47^{*}$ & $0 \cdot 30$ & $-0 \cdot 64^{* *}$ \\
\hline $\begin{array}{l}\text { Hours }{ }^{\mathrm{a}} \text { of relative humidity } \\
<40 \%\end{array}$ & $-0 \cdot 39$ & $-0 \cdot 27$ & $-0 \cdot 49^{*}$ & $0 \cdot 30$ & $0 \cdot 54^{*}$ & $0.50^{*}$ & $-0 \cdot 87^{* *}$ \\
\hline Hours stress ${ }^{b}$ & -0.27 & $-0 \cdot 35$ & -0.41 & $0 \cdot 26$ & $0 \cdot 49 *$ & 0.43 & $-0.84^{* *}$ \\
\hline Hours of temperature $<21^{\circ} \mathrm{C}$ & $-0 \cdot 38$ & $0 \cdot 54^{*}$ & -0.23 & 0.06 & 0.02 & 0.02 & -0.42 \\
\hline $\begin{array}{l}\text { Night-time hours }{ }^{\mathrm{a}} \text { of } \\
\text { temperature }<21^{\circ} \mathrm{C}\end{array}$ & $-0 \cdot 37$ & $0.57^{*}$ & -0.18 & -0.07 & -0.01 & -0.01 & -0.29 \\
\hline Grain filling duration (days) & $-0.47^{*}$ & $0 \cdot 30$ & $-0.55^{*}$ & $0.50^{*}$ & 0.28 & 0.36 & $-0.48^{*}$ \\
\hline Grain yield & -0.04 & $0 \cdot 52^{*}$ & 0.09 & 0.09 & -0.37 & $-0 \cdot 24$ & -0.09 \\
\hline Test weight & 0.21 & 0.33 & 0.44 & $-0 \cdot 21$ & $-0.63^{* *}$ & -0.38 & 0.02 \\
\hline
\end{tabular}

"Total hours during the grain filling period.

"Hours during the grain filling period of both temperature $>29^{\circ} \mathrm{C}$ and relative humidity of $<40 \%$.

*,** Significant at $P=0.05$ and $P=0.01$, respectively.

Table IV Correlations of environmental parameters with $\log _{10}$ variances, flour biochemical traits

\begin{tabular}{|c|c|c|c|c|c|c|c|}
\hline & $\begin{array}{l}\text { Flour } \\
\text { protein } \\
\text { content }\end{array}$ & Glutenin & Gliadin & $\begin{array}{l}\text { Low } M_{\mathrm{r}} \\
\text { SUP }\end{array}$ & $\begin{array}{l}\text { High } M_{\mathrm{r}} \\
\text { SEP }\end{array}$ & $\begin{array}{l}\text { Low } M_{\mathrm{r}} \\
\text { SEP }\end{array}$ & $\begin{array}{l}\text { SDS sedimentation } \\
\text { volume }(\mathrm{ml})\end{array}$ \\
\hline Hours" of temperature $>32^{\circ} \mathrm{C}$ & -0.37 & $0 \cdot 18$ & 0.23 & $0.61 * *$ & 0.25 & 0.44 & $-0.48^{*}$ \\
\hline Hours ${ }^{\mathrm{a}}$ of temperature $>35^{\circ} \mathrm{C}$ & $-0.48^{*}$ & $0 \cdot 20$ & $0 \cdot 18$ & $0.50^{*}$ & 0.22 & 0.35 & -0.44 \\
\hline $\begin{array}{l}\text { Hours }{ }^{\mathrm{a}} \text { of relative humidity } \\
<40 \%\end{array}$ & -0.22 & $0 \cdot 34$ & 0.33 & $0 \cdot 19$ & 0.22 & $-0 \cdot 10$ & $-0 \cdot 16$ \\
\hline Hours stress ${ }^{b}$ & -0.18 & $0 \cdot 38$ & 0.27 & 0.24 & $0 \cdot 30$ & -0.09 & -0.17 \\
\hline Hours ${ }^{\mathrm{a}}$ of temperature $<21^{\circ} \mathrm{C}$ & 0.44 & 0.01 & 0.29 & $-0.58^{*}$ & -0.22 & -0.45 & $0 \cdot 39$ \\
\hline $\begin{array}{l}\text { Night-time hours }{ }^{a} \text { of } \\
\text { temperature }<21^{\circ} \mathrm{C}\end{array}$ & $0.51^{*}$ & -0.06 & $0 \cdot 19$ & $-0.63^{* *}$ & $-0 \cdot 30$ & $-0 \cdot 50^{*}$ & 0.46 \\
\hline Grain filling duration (days) & $0 \cdot 20$ & $-0 \cdot 21$ & $0 \cdot 19$ & -0.23 & $-0 \cdot 48 *$ & -0.13 & 0.06 \\
\hline Grain yield & 0.07 & $-0 \cdot 15$ & $0 \cdot 06$ & -0.04 & 0.01 & 0.05 & -0.02 \\
\hline Test weight & 0.29 & $0 \cdot 12$ & -0.17 & -0.11 & 0.27 & -0.05 & $-0 \cdot 16$ \\
\hline
\end{tabular}

Total hours during the grain filling period.

${ }^{b}$ Hours during the grain filling period of both temperature $>29^{\circ} \mathrm{C}$ and relative humidity of $<40 \%$.

*,** Significant at $P=0.05$ and $P=0.01$, respectively. 


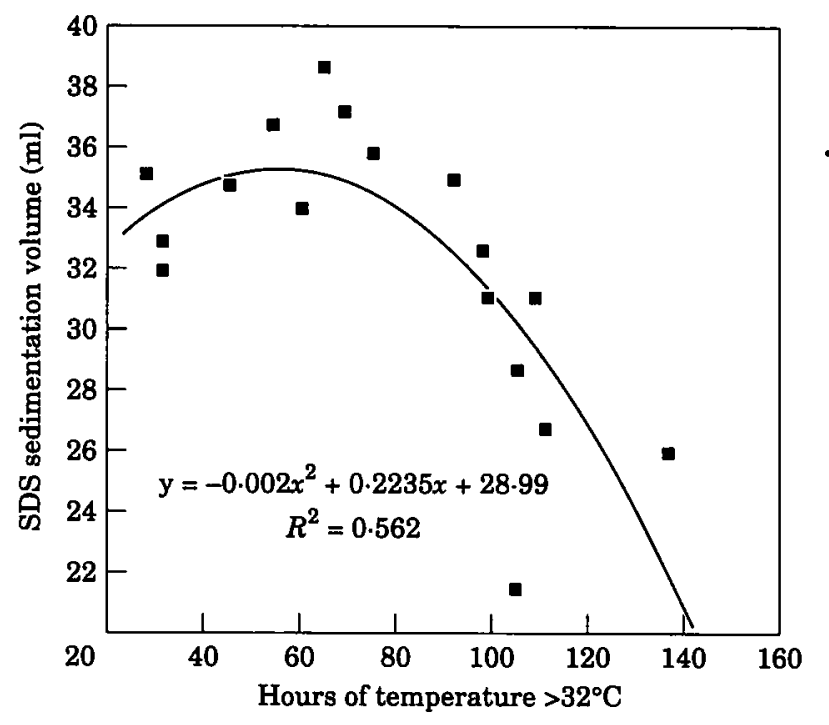

Figure 1 Relationship of SDS sedimentation volume and hours of temperatures $>32^{\circ} \mathrm{C}$ during the grain filling period.

Table V Summary of stepwise multiple regression models for prediction of mean flour protein composition from environmental variables

\begin{tabular}{|c|c|c|c|}
\hline Dependent variable & Factors in model & Partial $r^{2}$ & Cumulative $r^{2}$ \\
\hline Flour protein content & Grain filling duration & 0.22 & 0.22 \\
\hline Glutenin & $\begin{array}{l}\text { Night-time hours }{ }^{a} \text { of temperature }<21^{\circ} \mathrm{C} \\
\text { Hours }\end{array}$ & $\begin{array}{l}0.33 \\
0.18\end{array}$ & 0.51 \\
\hline Gliadin & $\begin{array}{l}\text { Grain filling duration } \\
\text { Hours of temperature }>32^{\circ} \mathrm{C}\end{array}$ & $\begin{array}{l}0 \cdot 30 \\
0 \cdot 11\end{array}$ & $0 \cdot 41$ \\
\hline Low $M_{\mathrm{r}}$ SUP & $\begin{array}{l}\text { Hours of temperature }>32^{\circ} \mathrm{C} \\
\text { Grain filling duration } \\
\text { Night-time hours }{ }^{\mathrm{a}} \text { of temperature }<21^{\circ} \mathrm{C}\end{array}$ & $\begin{array}{l}0.36 \\
0 \cdot 13 \\
0.08\end{array}$ & 0.57 \\
\hline High $M_{\mathrm{r}}$ SEP & Hours ${ }^{\mathrm{a}}$ of relative humidity $<40 \%$ & 0.29 & $0 \cdot 29$ \\
\hline Low $M_{r}$ SEP & Hours $^{\mathrm{a}}$ of relative humidity $<40 \%$ & $0 \cdot 26$ & 0.26 \\
\hline SDS sedimentation volume $(\mathrm{ml})$ & Hours ${ }^{2}$ of relative humidity $<40 \%$ & $0 \cdot 76$ & $0 \cdot 76$ \\
\hline
\end{tabular}

"Total hours during the grain filling period.

shown) was found to fit the non-linear model. The $r^{2}$ value of the non-linear model describing this relationship was 0.56 , notably higher than that of the linear model, $0 \cdot 39$. Figure 1 suggests the relationship between SDS sedimentation volume and temperatures during grain fill to be either curvilinear, with an optimal response at approximately $60 \mathrm{~h}$, or to be governed by a 'threshold' effect, in which SDS sedimentation volumes decrease after $80 \mathrm{~h}$ of high temperatures. Additional observations will be needed before the true relationship can be established.

Stepwise multiple regression analyses are summarised in Table V. Partial $r^{2}$ describes the fraction of the total variation in each biochemical variable explained by each respective independent variable. Combinations of environmental variables explained more of the variation in glutenin, gliadin; and low $M_{\mathrm{r}}$ SUP than single variables alone. For the remaining biochemical traits, no further variation could be explained. For SDS sedimentation volume, $76 \%$ of the variation was explained by the single variable, hours of relative humidity $<40 \%$. This level of prediction was not achieved with the remaining biochemical traits, indicating that more extensive monitoring of additional environmental parameters is necessary before predictive models can be developed. 


\section{DISCUSSION}

The absence of any strong correlation between protein content and environmental factors, other than with the duration of grain filling, is in contrast to several previous reports describing significant relationships between protein content and elevated temperatures during early grain filling ${ }^{9}$. However, Rao et al. ${ }^{10}$, after examining correlations of soft wheat protein content with environmental factors at 10 locations in the Pacific Northwest, concluded that the primary environmental factors conditioning protein content differed among locations. While increased temperatures during grain filling were most often associated positively with protein content, negative correlations were observed at some locations. Evidently, protein content is affected by a host of environmental factors in addition to temperatures during grain filling, such as the duration of grain filling, soil type and fertility, soil moisture availability, disease pressure, etc.

Our results suggest that protein quality, as measured by the SDS sedimentation test, is more susceptible to environmental modification than flour protein content, or the level of the different protein fractions as measured by SE-HPLC. Of interest is the close similarity between the response of SDS sedimentation to environmental factors in this report, and the response of dough strength in Australian wheats, as measured by the Extensigraph (compare Fig. 1 of this report with Fig. 3 of Blumenthal et al. ${ }^{12}$ ). A reduction in protein quality with increased stress appears to be common to both Australian and U.S. wheats.

The precise cause of the decline in SDS sedimentation volumes observed with increasing frequencies of high temperatures and low relative humidities remains to be determined. Blumenthal et al. ${ }^{12}$ have proposed a model whereby increased synthesis of gliadin protein at the expense of glutenin, under conditions of high temperatures, results in a decrease in protein quality. In their work, elevated gliadin was observed in lines subjected to stress in the middle of the grain filling period, but it was also associated with an increase in protein content. Different cultivars also differed in their response, with some showing essentially no change in gliadin content under elevated temperatures. An increase in gliadin content with increased flour protein content is a commonly observed effect ${ }^{14}$. In the present study, both glutenin and gliadin were negatively associated with increased temperatures during grain filling, while the production of flour non-gluten protein (low $M_{\mathrm{r}}$ SUP and SEPs) was elevated. The apparent discrepancy between the present report and previous investigations ${ }^{12}$ might be due to slightly different approaches to the determination of gliadin content. In our research, monomeric protein of $M_{\mathrm{r}}$ range $25 \mathrm{k}-100 \mathrm{k}$ was separated into SEP and SUP (gliadin) fractions, while in the Australian work, it was retained as one fraction termed 'gliadin'. Previously ${ }^{15}$, we have shown the SEP of $M_{\mathrm{r}}$ range $25 \mathrm{k}-100 \mathrm{k}$ to contain proteins that co-migrate with gliadins on SDS polyacrylamide gels. Even though the classical definition ${ }^{17}$ of gliadin is protein unextractable in aqueous solutions but extractable in $70 \%(\mathrm{v} / \mathrm{v})$ alcohol, it has been known for some time that some of the more hydrophilic gliadins may be extracted to a certain extent with aqueous solutions $^{18}$. Thus, both studies suggest that the synthesis of some monomeric proteins is increased under heat stress. The precise identity of these proteins merits further investigation.

The correlations between SE-HPLC protein fractions and environmental factors were not of the same magnitude as those observed for SDS sedimentation volumes, suggesting that the changes in SDS sedimentation volumes are not due to changes in protein profiles alone. The SDS sedimentation test is an interactive system ${ }^{19}$, however, in which gluten swelling and the interaction of starch and gluten are vital. Recently, Carver $^{20}$ described a correlation of SDS sedimentation volume with grain hardness (and hence, damaged starch). Thus, changes in flour biophysical phenomena, including protein-starch interactions and the extent of the gluten network ${ }^{21}$, might be responsible for environment-dependent changes in SDS sedimentation volumes.

The high correlation of SDS sedimentation volumes with environmental factors fulfills the primary goal of finding a simple biochemical test that can be predicted by environmental modelling. Different users of wheat flour could benefit from this information if their particular product requirements are correlated with this relatively simple assay. SDS sedimentation volumes are correlated with measures of dough strength, such as Mixograph tolerance, and with loaf volumes, as determined by straight dough pup loaf tests ${ }^{4}$, although the correlation of SDS sedimentation volumes with commercial quality requirements is not widely known. Models for the prediction of optimal environments for the production of high quality wheat need not be overly complex. Identification 
of environments exceeding the threshold of $80 \mathrm{~h}$ of temperatures $>32^{\circ} \mathrm{C}$ during grain filling could serve as a means of identifying optimal production areas. Owing to highly variable weather patterns within the Great Plains, however, such areas will vary from year to year, but can be identified easily through computer databases.

There has been renewed interest in examining the effects of environment on wheat quality. It should be remembered, however, that cultivated wheat is really a collection of ecotypes (variants within a species ecologically and genetically adapted to local environments). The diverse regions in which wheat is cultivated, ranging from semiarid zones in the Great Plains and Australia, to maritime climates in Europe and the eastern U.S.A., plus the genetic diversity within the species arising from selection of locally adapted types, will make it highly unlikely that environmental models for the prediction of either flour biochemistry or quality will be applicable in multiple regions worldwide. Within each major cultural environment (e.g. the Great Plains), however, more extensive environmental monitoring could result in quite accurate models for the prediction of protein quality.

\section{Acknowledgment}

Financial support from Anheuser-Busch, Inc., is gratefully acknowledged. Joint contribution of the U.S. Department of Agriculture, Agricultural Research Service (USDA-ARS) and the Department of Agronomy, University of Nebraska-Lincoln as Journal Series Paper No. 10778. Mention of firm names or trade products does not imply that they are endorsed or recommended by the U.S. Department of Agriculture or the University of Nebraska over other firms or products not mentioned.

\section{REFERENCES}

1. Busch, R.H., Shuey, W.C. and Frohberg, R.C. Response of hard red spring wheat (Triticum aestivum L.) to environments in relation to quality characteristics. Crop Science 9 (1969) 813-817.

2. McGuire, C.F. and McNeal, F.H. Quality response of 10 hard red spring wheat cultivars to 25 environments. Crop Science 14 (1974) 175-180.

3. Baenziger, P.S., Clements, R.L., McIntosh, M.S., Yamazaki, W.T., Starling, T.M., Sammons, D.J. and Johnson, J.W. Effect of cultivar, environment and their interaction and stability analyses on milling and baking quality of soft red winter wheat. Crop Science 25 (1985) 5-8.

4. Peterson, C.J., Graybosch, R.A., Baenziger, P.S. and
Grombacher, A.W. Genotype and environment effects on quality characteristics of hard red winter wheat. Crop Science 32 (1992) 98-103.

5. Lukow, O.M. and McVetty, P.B.E. Effect of cultivar and environment on quality characteristics of spring wheat. Cereal Chemistry 68 (1991) 597-601.

6. Hubbard, K.G., Rosenberg, N.J. and Nielsen, D.C. Automated weather data network for agriculture. Joumal of Water Resources Planning and Management 109 (1983) 213222.

7. Hubbard, K.G. and Hanks, R.J. Climate model for winter wheat yield simulation. Foumal of Climate and Applied Meteorology 22 (1983) 698-703.

8. MacRitchie, F. Physicochemical properties of wheat proteins in relation to functionality. Advances in Food Nutrition Research 36 (1992) 2-87.

9. Johnson, J.A., Khan, M.N.A. and Sanchez, C.R.S. Wheat cultivars, environment and bread-baking quality. Cereal Science Today 17 (1972) 323-326.

10. Rao, A.C.S., Smith, J.L., Jandhyala, V.K., Papendick, R.I. and Parr, J.F. Cultivar and climatic effects on the protein content of soft white winter wheat. Agronomy Journal 85 (1993) 1023-1028.

11. Blumenthal, C.S., Batey, I.L., Bekes, F., Wrigley, C.W. and Barlow, E.W.R. Seasonal changes in wheat-grain quality associated with high temperatures during grain filling. Austratian Joumal of Agricultural Research 42 (1991) 21-30.

12. Blumenthal, C.S., Barlow, E.W.R. and Wrigley, C.W. Growth environment and wheat quality: the effect of heat stress on dough properties and gluten proteins. Foumal of Cereal Science 18 (1993) 3-21.

13. Approved Methods of the American Association of Cereal Chemists, AACC 7th edn, St Paul, Minnesota (1983).

14. Graybosch, R.A., Peterson, C.J., Moore, K.J., Stearns, M. and Grant, D.L. Comparative effects of wheat flour protein, lipid and pentosan composition in relation to baking and milling quality. Cereal Chemisiry 70 (1993) 95-101.

15. Graybosch, R.A., Peterson, C.J., Hansen, L.E., Worrall, D., Shelton, D.R. and Lukaszewski, A. Comparative flour quality and protein characteristics of $1 \mathrm{BL} / \mathrm{IRS}$ and $1 \mathrm{AL} /$ IRS wheat-rye translocation lines. Journal of Cereal Science 17 (1993) 95-106.

16. SAS User's Guide: Statistics (1985) SAS Institute, Cary, North Carolina.

17. Osborne, T.B. The protein of the wheat kernel. Publ. No. 84, Carnegie Institute Washington, Washington, D.C. (1907).

18. Mattern, P.J. and Sandstedt, R.M. The influence of the water-soluble constituents of wheat flour on its mixing and baking characteristics. Cereal Chemistry 34 (1957) 252-257.

19. Eckert, B., Amend, T. and Belitz, H.D. The course of the SDS and Zeleny sedimentation tests for gluten quality and related phenomena studied using the light microscope. Zeitschrift fuir Lebensmittel-Untersuchung und-Forschung 196 (1993) 122-1 25.

20. Carver, B. Selection for kernel hardness in bread wheat populations: Implications for quality. Agronomy Abstracts (1993) 84.

21. Gupta, R.B., Khan, K. and MacRitchie, F. Biochemical basis of flour properties in bread wheats. I. Effects of variation in the quantity and size distribution of polymeric protein. Joumal of Cereal Science 18 (1993) 23-4l. 